\title{
DEFENCE HERITAGE IN A STATE OF RUIN: THE ARCHAEOMETRIC STUDY OF 'DELLA FAVA' CASTLE IN SARDINIA (ITALY)
}

\author{
C. GIANNATTASIO, S.M. GRILLO, E. PILIA \& M.S. PIRISINO \\ Department of Civil-Environmental Engineering and Architecture, Cagliari University, Italy
}

\begin{abstract}
Defence heritage has always had a dominating presence in the landscape. It speaks of the passing of time in various countries, and it is a witness to a complex system of relationships between fortified architecture and documenting local materials and techniques. Innumerable researches have been carried out to study these ruined structures frequently without evaluating their valuable chronological role of 'benchmark' in the landscape. In Sardinia these studies, principally related to the dating, history and evolution of this heritage, are complicated by the lack of documented sources and by the small number of castles and ruins still available. The present research contributes to more insight in this field, reflecting on the study of medieval fortified heritage, which is in a state of ruin in north-east of Sardinia (12th13th centuries), and it proposes an interdisciplinary protocol of research for this architecture. The object is the investigation of the 'della Fava' castle (Posada), which represents one of the most important defensive architectural systems on the coast. Its structures have been studied in depth through a series of archaeometric analyses, based on surveys, typological, architectural and construction techniques, as well as petro-mineralogical inspection, with the purpose of reconstructing dimensional, material and constructive aspects of the traditional masonry techniques. This article allows to achieve two different aims: (1) to understand how a structure is made and consequently to define the correct conservation and design project; and (2) to identify typological and dimensional constants that referred to a specific geological context and period; these constants can be a useful tool for comparing and dating coeval structures, such as 'minor architecture', that are difficult to date.
\end{abstract}

Keywords: chronologies, fortified system, masonry techniques, ruins.

\section{STUDIES ON THE DEFENCE HERITAGE IN SARDINIA (CG)}

This article presents a part of the results of an in-progress research, which is focused on the investigation of the Sardinian fortified system. In Sardinia, the topic about medieval defence heritage (12th-13th centuries), principally as regards its dating, its history and its evolution, even though widely debated, is still an open issue, probably due to the unavailability of documented sources and to the less number of castles, or ruined castles still available [1]. In this context, innumerable researches have been carried out to study these ruined structures with historical [1-7], archaeological [8] and typological aspects [9], but frequently without evaluating their valuable chronological role of 'benchmark' in the landscape [10]. The research on the Sardinian fortified heritage, which is being carried out by the team of the School of Restoration in the University of Cagliari, stems from the awareness that, in the local area, in-depth studies on dating minor and monumental architecture are still a few [11-16]. From this lack of knowledge began the choice to investigate the fortified architecture, a rich heritage which, despite its state of ruins, may offer the best conditions for the analysis of its structures. The study started with the analysis of the fortified

This paper is part of the Proceedings of the 3rd International Conference on Defence Sites: Heritage and Future (Defence Heritage 2016)

www.witconferences.com 
systems, such as urban and suburban walls, castles, fortresses, bunkers, defence towers and lookouts, in reference to the various regional background, dating between the 10th and 19 th centuries. The choice comes from the knowledge that such historic buildings are usually characterized by intense and diffuse damage. Their condition facilitates the analysis of masonry structures, both in elevation and in section. Furthermore, these buildings are in general philologically dated, and therefore may represent valid dating points of reference [17]. The fortified system has been studied through a multidisciplinary approach ranging from surveys and archival and historical investigations to the study of the typological, architectural and construction techniques with a particular attention to the masonries. The case study presented here about della Fava castle, which was built in the 13th century and is situated in the medieval burg of Posada, is an application of this methodology. Specifically, masonry samples corresponding to the foundation phase and not compromised by further interventions have been selected and analysed. Consequently, they were examined through the study of techniques, measures and materials, following an archaeological approach, in order to put in evidence the constructive peculiarities and materials. In addition, in this direct investigation, the macroscopic material analysis and masonry textures have been supported by mineralogical petrographic investigations which have been carried out in order to characterize the composition of binders and aggregate fractions. Specifically, the study included image rectification, archaeological survey and mapping of materials of the eastern front of the keep and of the north-eastern side of the upper fortified wall, and a map of the localization of samples. Della Fava castle represents one of the most important defensive architectural systems on the north-eastern Sardinian coast and it contributes to define a chronological repertory of techniques in this geographic area, increasing knowledge for the possible new connections between dated and not-yet-dated architectures.

\section{DEFENCE HERITAGE IN STATE OF RUIN IN NORTH-EAST OF SARDINIA}

\subsection{Defence heritage in state of ruin (EP)}

The north-east of Sardinia, in the past called Gallura kingdom, is characterized by a wide variety of fortified architecture in state of ruin that is common in all the Sardinian regions. In general, this is constituted by a complex framework of fortified structures, which differ in terms of typology such as castles, costal towers, defence walls, and blockhouses, and period of construction. They also vary in materials, location, building techniques and history, creating a various heritage and showing a wide range of problems related to their state of conservation and to the interventions that in the past have been done for their safeguard. Their abandon began with the end of the Judicial period, when these fortifications were neglected for their uselessness and partially demolished after 1820, when a law called 'delle chiudende' was imposed to close all the lands. As a consequence, part of the materials from the fortifications was so used to build enclosures [3]. However, the present advanced state of ruination is also due to different factors, such as the poor coexistence of the building materials, their expositions to differing weather conditions as well as difficult accessibility to these structures due to their isolated position. Furthermore, the process may be originated from the long period of neglect and misunderstandings that have characterized the Sardinian policies during the past century when in Italy, for the first time, there was a new position in favour of safeguarding them from ruins. In fact, in 1906, the state issued the circular number 18 signed by Corrado Ricci. It defines ruins as 
all remains from old buildings, archeologic fragments, epigraphs and different building elements. Each of them, placed in their original location, has paramount value because it is a document that tell about the history of the building, it conserves the signs of past uses of the structures and it could be useful to reconstruct the general history. Every artistic or historic fragment cannot be changed in position or demolished but they must be preserved and exposed to the community [18].

Ruins appeared thus, monuments to respect and preserve, but this was only the first step for their real protection. Despite these progresses, Sardinia, marginalized and isolated from the dominant intellectual currents of the mainland, got little attention to this heritage. In the island, the first theoretical interest for the heritage in ruins began between the end of the 9th and 10th centuries, under the influence of important intellectual personalities such as Filippo Vivanet, Carlo Aru and Dionigi Scano, superintendent architects in this period. They worked for the promotion of interventions that redeemed ruins from their wreckage and that safeguarded their picturesque pathos for guarantying the authenticity of the structures. At the same time, on the practice, they carried out debated interventions on ruins, with a massive reintegration of materials [19]. Furthermore, they focused on interventions only on the most important sites, still neglecting the minor architectures that were left to continue their process of ruination. As regards the north-east area, the Sardinian fortified heritage was involved in an important period of restoration - only around 1960 s, i.e. sixty years of delay, comparing with all the other Italian regions. It was supported by national financial resources for the meridional areas (Cassa del Mezzogiorno) and supervised by the Arch. Roberto Carità. In these years, the general tendency of reintegration, even after inspired by the ICOMOS and Venice Charter's principles, digressed from all the limits imposed by the regulations and arrived to the full reconstruction of elements, often not documented and historically justified [20]. Della Fava castle is a clear example of defence heritage in state of ruins that was restored between 1960s and 1980s, with particular attention to the reconstruction of the mastio. Undoubtedly, the definition of projects in the Sardinian territory was, and is, complex. This means not only to preserve structures and transmit their values but also to design an intervention in the landscape. Following the Brandi's theory, ruins are not only witness of human activity, showing something different from their original state, but they are a unique piece of art with their picturesque surrounds. Their conservation stems from the historic instance that considers ruins as fragmented witnesses still recognizable as products of human activity. At the same time, defence ruins may also be considered from the view of aesthetical instance. Indeed, they are not a wreck as they qualify the natural space with which they are surrounded. Ruins and nature work together to create a unique 'piece of art'. As Brandi [21] said these monuments have acquired during the time 'an indissoluble facies' that should be conserved. For all these reasons, the study of della Fava castle contributes to the knowledge of this heritage that needs to be protected, even though useless, for its importance in the past and the present in the culture of the community and in the history of the landscape.

\subsection{Medieval fortified heritage (MSP)}

The della Fava castle had an important defensive role and control of the territory, within the kingdom of Gallura [22]. In the Middle Ages, this region was one of the four local kingdoms that divided the Sardinian territory (Fig. 1). They took their name from the regions where they extended: Arborea, Cagliari, Gallura and Torres, and they reflected the natural topographical 

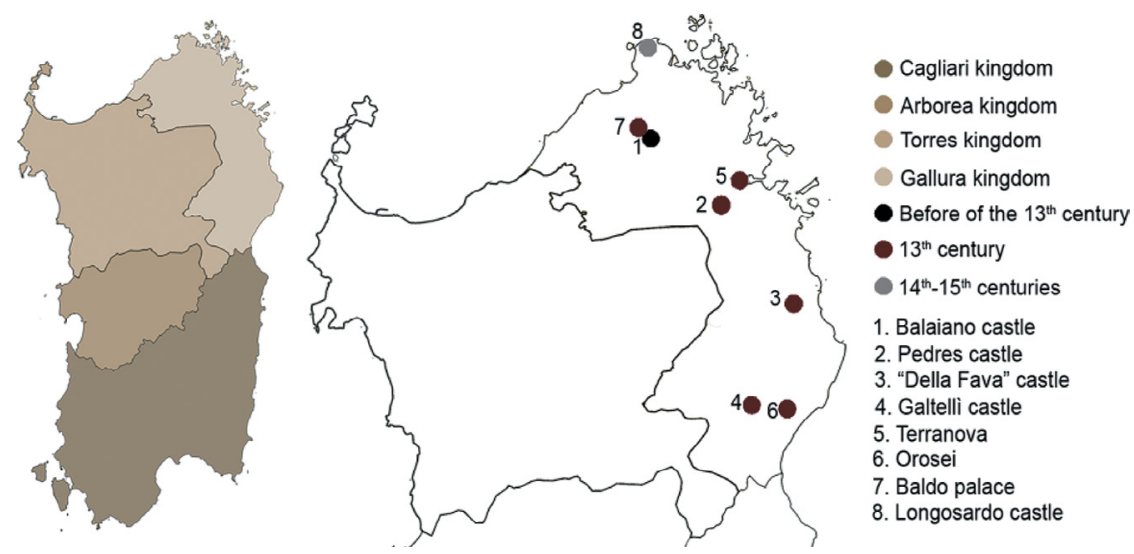

Figure 1: The medieval Sardinian kingdoms with the localization of the Gallura fortified system (edited by M.S. Pirisino).

distribution and were independent of each other even though similar in their political, legal and administrative aspects [23-27]. Their history followed different destinies and ended in 1478 with the fall of the last sovereign state and with the complete subjugation of the island under the crown of Aragon. In detail, the past of the Gallura kingdom has been absolutely influenced by the presence of the Pisan authority influencing and increasing the significance of the built fortifications and their development. In the kingdom of Gallura, which is provided with a natural fortified system constituted by mountains and wild lands, there are not many fortifications, and the most important arises in defence of the coastal side (Fig. 1). Nevertheless, it can be distinguished into different phases in the phenomenon called 'incastellamento' (Fig. 1) [2-5, 27]. The first phase is characterized by fortifications built in the 12th century, considered as a real stronghold, which had been built on the summit of an isolated hill; they were difficult to access because they were placed in a strategic position such as near roads or rivers or plains. The Balaiano castle in Luogosanto is an example. The second phase concerns the numerous castles and burg erected in the 13th century. They were the expression of local authorities that succeeded the old reigns and brought forth the transformation of the settlement. Examples of this phase are Pedres, della Fava and Galtellì castle as well as fortified cities such as Terranova and Orosei and Baldo palace. The last phase consists of a few new castle, built in the 14th-15th centuries, under the military expansion of the Aragonese such as the Longosardo castle in Santa Teresa di Gallura. In the 15th century, these castles lost their defensive function. As already said, they sometimes were destroyed or totally abandoned for few centuries. Currently they are in a state of ruination.

\section{THE CASE STUDY OF DELLA FAVA CASTLE}

\subsection{Architecture coast (MSP)}

Della Fava castle is located on the summit of a limestone hill, above the medieval burg of Posada, which dominates the surrounding flat landscape (Fig. 2). It is positioned in a strategic site: on the one hand, the fortress controlled the valley underneath and its seaside; on the other hand, being the castle near an important old coastal road, it supervised the limits with the reign of Cagliari. 

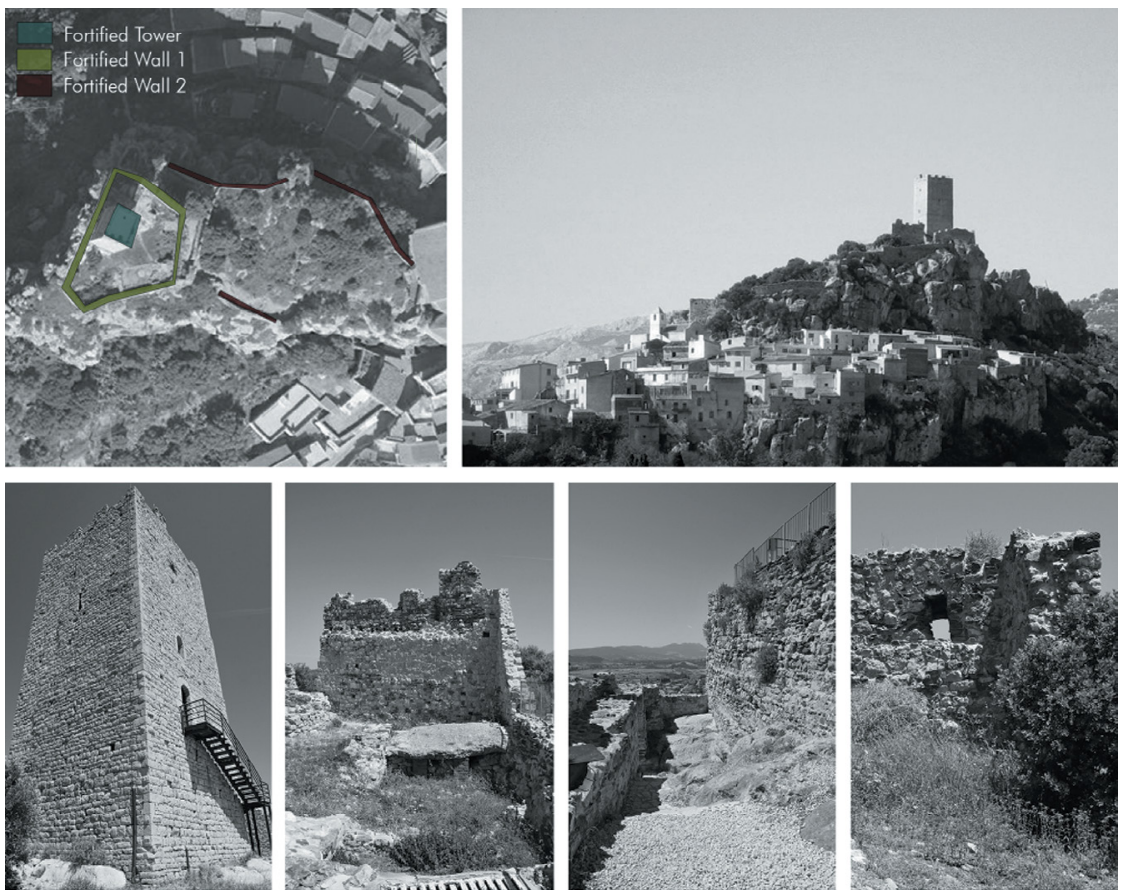

Figure 2: Della Fava castle. Plan scheme of the fortified complex, with the identification of the building system; view of the fortified complex and the burg of Posada; the fortified tower; the fortified wall near the tower; the second fortified wall; the passageway (edited by M.S. Pirisino).

The ruined castle shows a plan scheme similar to fortified complex dated to 13 th century (Fig. 2). It is placed among two forecourts, which fit the morphology of the outcrop. The first is almost completely lacking, while the upper one, situated in the north-western side, presents an irregular plan. Between the two forecourts, there is a passageway to the mastio. The entrance to this upper area is on the northern side and, within, there are the donjon, a rectangular space and few cisterns. The fortified tower is located on the north-west side and exhibits a quadratic irregular plan (about $7.50 \mathrm{~m}$ for sides), with a height of about $20 \mathrm{~m}$. In the eastern side of the tower, at a height of about $4.50 \mathrm{~m}$, there is the entrance, observed with a frame similar to other Gallura castles in shape, and it is on the axis with a long window and a tight embrasure. In few parts, there is crenellated parapet. The historical references about this fortified architecture are very fragmentary, but, as many researchers claim [28], it is possible to date the castle at second half of the 13th century. The castle was mentioned, for the first time, in a nautical map called 'Carta Pisana', dated around 1275 [28] and in a peace accord in 1294. At the end of the 13th century, the presence of the della Fava castle in historical references increases. As a matter of fact, from the 14th to the middle of the 15th century, the castle, due to its strategical position, was witness to the military conflict between the Aragon's crown and the last local authority. At the end of the same century, losing its military function, this fortified complex was gradually abandoned. In the 1960s, it was involved in restoration works, based on the reintegration of ruins, and in 2012, parts of the fortified wall were modified through interventions of consolidation. 


\subsection{Masonry techniques (MSP)}

The investigation paid particular attention to the masonries, both of the eastern front of the fortified tower and of the north-eastern side of the upper fortified wall (Fig. 3). As regards the structural details, the wall thickness of the mastio is around $1.40 \mathrm{~m}$, while the section of the fortified wall is around $0.90 \mathrm{~m}$, and it shows a stuck core. An in-depth analysis of the masonries (Fig. 3) allowed us to identify two different masonry types that can be classified in the following way: the first one is a roughly hewed squared masonry (M01), and the second is a rough stone masonry (M02). The masonry M01 is built in limestone with roughly hewed ashlars, with cornerstone slightly squared. It is located in correspondence with the fortified tower. The angular structures (M01a) are composed of slightly squared elements, arranged in staggered roughly horizontal rows. The wing and tip are placed alternatively, sewing the edges effectively and obtaining the best connection between intersecting walls and great strength in the corners. Dimensional analysis of the elements of masonry techniques can be seen in the table n. 1 (Fig. 3). The masonry is characterized by $2-3$ sub-horizontal rows (min. $32.60 \mathrm{~cm}$, max. $91 \mathrm{~cm}$, mean $59.85 \mathrm{~cm}$ ). This is underlined by the presence of regularity in geometry and disposition, and by use of wedges in stone and brick, for filling the gaps. The size of the roughly hewed stony elements (M01b) is a variable, and it depends on their constructive position. In fact, the greater presence of elements with a considerable height
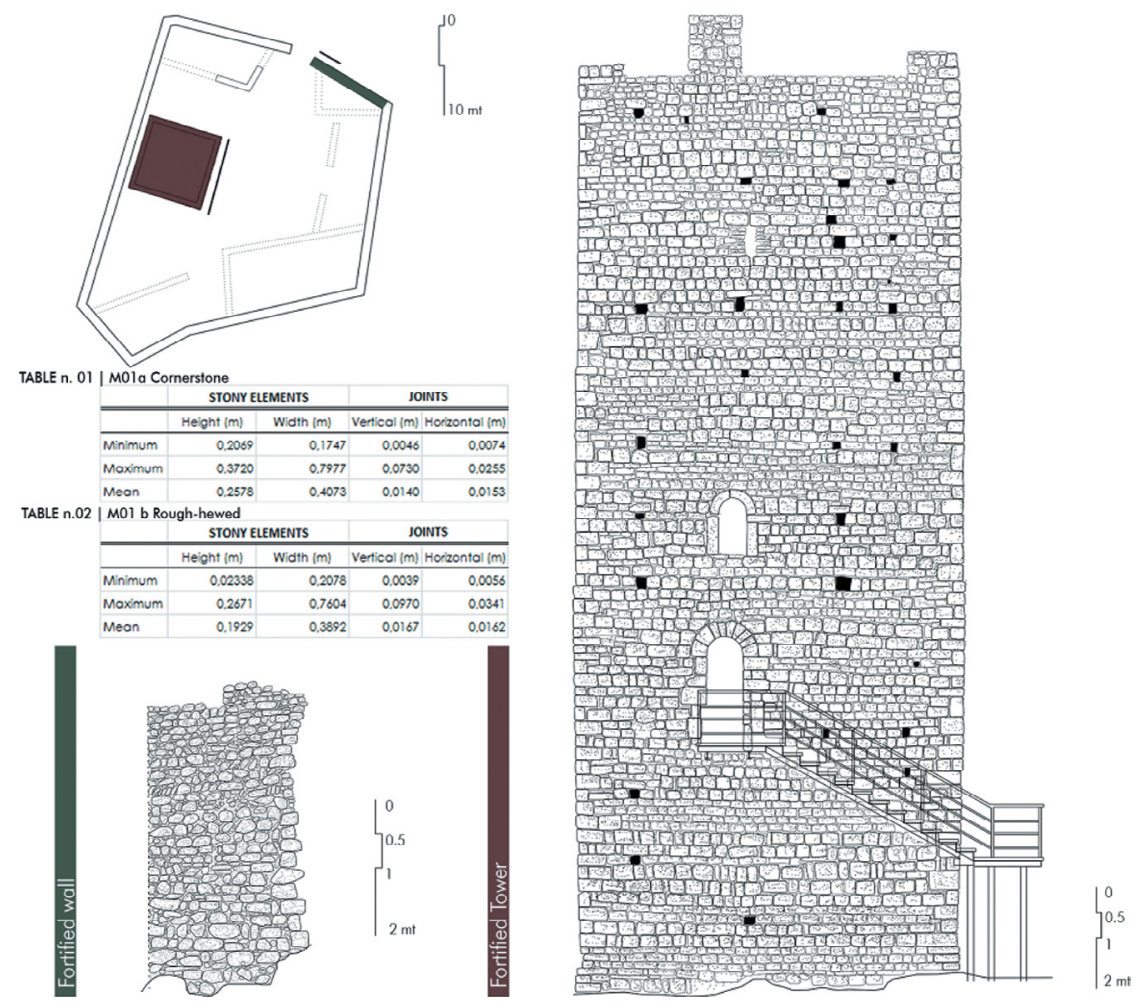

Figure 3: The east front of the fortified tower and wall. Masonry techniques and dimensional analysis of the elements (edited by M.S. Pirisino). 
in the lower part of the structure can be observed. Dimensional analysis of the elements of masonry techniques can be seen in the table n. 2 (Fig. 3). There are also marks of the construction phase, such as putlog holes. This masonry technique is mainly in view. The masonry M02 instead is constituted by a rough stone masonry built with ashlars of several lithotypes characterized by various shapes and sizes (Fig. 3). It is located in correspondence with the fortified walls. Moreover, many wedges of brick and stone have been used in order to fill the interstitial segments and to maintain the horizontality. It is interesting to observe the presence and the identification of cantieri, horizontal levels usually observed in every 2-4 rows of stones. Every cantiere is approximately $30-60 \mathrm{~cm}$. Joints and beddings are characterized by lavish mortar. All masonries are not plastered.

\subsection{Materials (SMG)}

Posada is sited in a heterogeneous territory characterized by alluvial and coastal deposits; limestones, dolomitic limestones and dolomitic stones; conglomeratic sandstones, quartzite and phyllites; granitoids and metamorphic rocks (Italian geological chart-ISPRA 1:100.000, paper 195 - Orosei). In the castle the materials, used both in the form of rough stone or ashlars and in aggregates to make mortars, are those from the local historic quarries. In detail, the
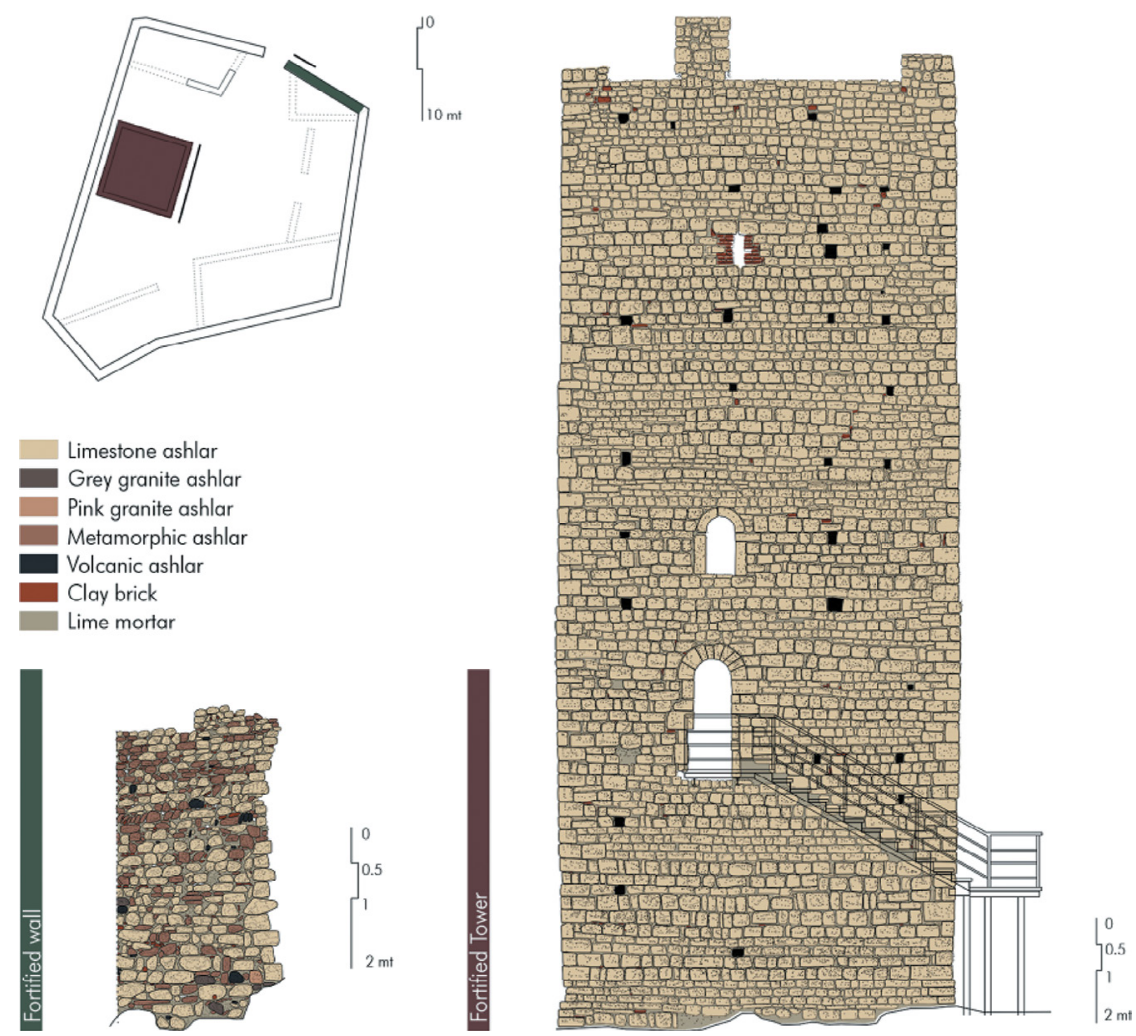

Figure 4: The eastern front of the fortified tower and wall. Mapping of materials (edited by M.S. Pirisino). 

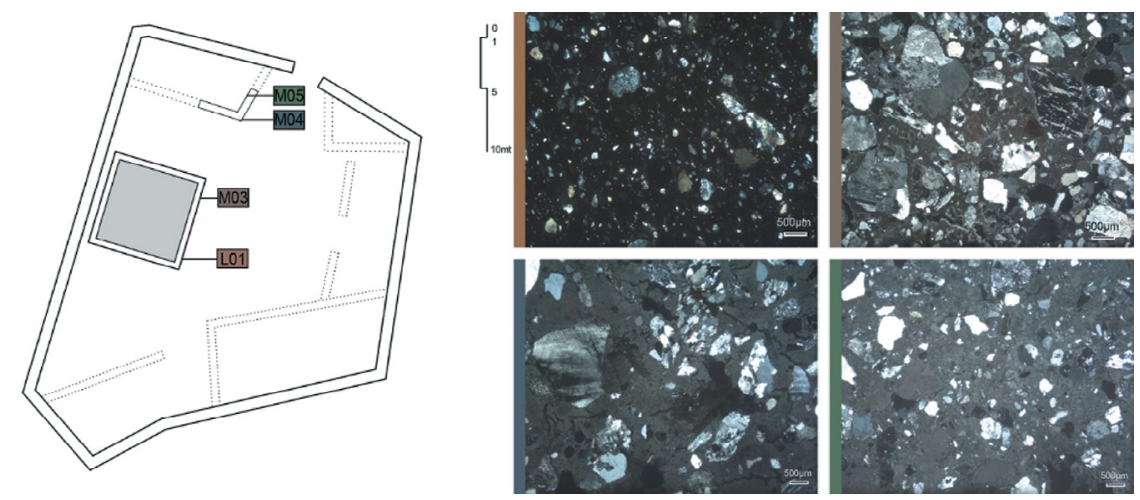

Figure 5: Localization of the samples; thin sections of historic lime mortar and clay brick, concerning the eastern front of the fortified tower and wall (edited by M.S. Pirisino).

masonry of the fortified tower is characterized by limestone ashlars of white, grey and yellow colours (Fig. 4). Instead, the masonries of the fortified walls are constituted by a mixture of rough stone and ashlars of limestone, pink granite, ashlars of metamorphic rocks, from light to dark colours, and by volcanic stone that has been used rarely. Historic red clay bricks have been used mainly as wedges and for the execution of the tight embrasure in the fortified tower. The macroscopic analysis of the materials and masonry textures has been supported by mineralogical and petrographic analysis. Four samples have been collected from the historical masonries: three are mortars (M03, M04, and M05) and one is an historical clay brick (L01). L01 and M03 concern the tower and the ruin of rectangular space while M04 and M05 were sampled in the north-western area of the court (Fig. 5). They have been analysed using optical microscope to characterize the composition of the binder and aggregate fractions (Fig. 5). In summary, mortars M03 and M04 are characterized by an aggregate constituted by fragment of metamorphic rocks (quartz, feldspar and not many femic minerals) in calcic lime binder. The granulometry is a variable and the mixtures are not particularly homogeneous. The sample M03 is different from the mortar M04 for the low binder/aggregate ratio. Mortar M05, instead, is characterized by an aggregate of thin crystals of quartz, a calcic lime binder and a high binder/aggregate ratio. It can be observed that there is a substantial presence of unburnt lime inclusions and shrinkage cracks. The historical red clay brick (L01) consists mainly of fired clay matrix and quartz feldspar and some mica (brown) and quartzite particles. It is characterized by a coarse and abundant aggregate.

\section{CONCLUSION}

The main aim of the current article was to improve the knowledge about the Sardinia defence heritage from a technical and constructive point of view. The results of the research facilitate the dating of coeval episodes of architecture, such as castles, churches and traditional buildings, that are present in the other historical area of the Sardinia. In fact, they are often abandoned or demolished because of absence of recognition of their historical and cultural values. Furthermore, the research has contributed (1) to understand how a structure is made, and consequently it could support the definition of correct conservation and design projects; and (2) to identify typological and dimensional constants referred to a specific geological context and period; these constants can be a useful tool for comparing and dating coeval structures, such as 'minor architecture', that are difficult to date. 


\section{ACKNOWLEDGEMENTS}

Elisa Pilia gratefully acknowledges Sardinia Regional Government for the financial support of her PhD scholarship (P.O.R. Sardegna F.S.E. Operational Programme of the Autonomous Region of Sardinia, European Social Fund 2007-2013 - Axis IV Human Resources, Objective 1.3, Line of Activity 1.3.1.).

Maria Serena Pirisino has carried out research activities during her $\mathrm{PhD}$ programme in Civil Engineering and Architecture in the University of Cagliari, XXIX cycle, in the academic year 2014/2015, with the support of a scholarship financed with the resources allocated by INPS - Management of Public Employees, as part of the initiatives of Homo sapiens sapiens.

\section{REFERENCES}

[1] Poisson J.M., Castelli medievali di Sardegna: Dati storici e dati archeologici. Archeologia Medievale, XVI, pp. 191-204, 1989.

[2] Carta Raspi R., Castelli medioevali di Sardegna, Cagliari, Della fondazione Il Nuraghe ed., 1933.

[3] Fois, B. ed., Castelli della Sardegna Medioevale, Arkadia: Cagliari, p. 11, 2012.

[4] Day, J., Castelli, città fortificate e organizzazione del territorio in Sardegna dal secolo dodicesimo al quattordicesimo. Castelli Storia e Archeologia, Conference Acts, eds. A. Settia \& R. Comba, Cuneo, pp. 115-121, 6-8 Dicembre 1981.

[5] Castellaccio, A., Note sul castello della Fava. Medioevo saggi e rassegne, 15, pp. 55-83, 1990.

[6] Milanese, M., Paesaggi rurali e luoghi del potere nella Sardegna Medievale. Archeologia Medievale, XXXVII, pp. 247-258, 2010.

[7] Soddu, A., Incastellamento in Sardegna. L'esempio di Monteleone, Quaderni di Castra Sardiniae 1, Ae Aonia ed., 2013.

[8] Milanese M., L'attività di ricerca in Sardegna e in Tunisia delle Cattedre di Metodologia della Ricerca Archeologica e di Archeologia Medievale delle Università di Pisa e di Sassari. L'Africa Romana. Lo spazio del Mediterraneo occidentale: geografia storica ed economia, eds. Khanoussi, M. \& Ruggeri, P., Vismara, C. Proceedings of the XIV Conference, Carocci ed.: Rome, pp. 2429-2474, 2002.

[9] Coroneo, R. Architettura romanica dalla metà del Mille al primo '300, 'Storia dell' arte in Sardegna' series, Ilisso: Nuoro, sch. 177, 1993.

[10] Fiorino, D. \& Pilia, E., Il rudere come time-landmark del paesaggio storico, in the international and interdisciplinary periodical. Agribusiness Paesaggio \& Ambiente, XVII(2), pp. 108-114, Marzo 2014.

[11] Giannattasio, C, Stato dell'arte in Sardegna. Lo studio delle tecniche costruttive storiche: stato dell'arte e prospettive di ricerca, ed. V. Pracchi, Nodo Libri: Como, pp. 53-57, 2008.

[12] Giannattasio, C. \& Grillo, S.M., The Mezzaspiaggia tower (Cagliari-Italy): the dating of structures by the metrological-chronological analysis of masonry and the petrogeochemical stratigraphy of building materials. Proceedings of the $37^{\circ}$ ISA., ed. I. Turbantini Memmi, Springer ed.: Siena, Berlin-Heidelberg, pp. 489-494, 2011.

[13] Giannattasio, C. \& Pintus, V., Il complesso claustrale di San Francesco a Stampace in Cagliari. Arkos fifth series n. 3-4, pp. 47-68, 2013.

[14] Giannattasio, C., Grillo, S.M. \& Pirisino M.S., The Rectorate Building of the University of Cagliari (18th-20th century): Archaeometric Analysis of Masonries. Arkos fifth series n. 9-10, pp. 30-52, 2015. 
[15] Giannattasio, C., Grillo, S.M. \& Murru S., The Western Sardinian Coast Defensive Towers (16th-17th century): An interdisciplinary approach for the chronological definition of masonries. Proceedings of 4th Annual International Conference on Architecture, ed. G.T. Papanikos, Athens, 7-10 July 2014, ATINER'S conference papers series, Athens Institute for Education and Research, Athens, pp. 3-17, 2014.

[16] Fiorino D., Giannattasio C. \& Grillo S.M., Interpretazioni stratigrafiche di malte e intonaci nelle chiese rurali della Sardegna: San Giovanni Battista a Bortigali (NU) in Materiali e Strutture. Problemi di conservazione, new series IV, n.8, Quasar di Severino Tagnon s.r.l ed.: Rome, pp. 21-30, 2015.

[17] Fiorino, D., Giannattasio, C. \& Silvana S.M., Fortificazioni e cronologie. Protocolli conoscitivi per la conservazione. Verso un atlante dei sistemi difensivi della Sardegna, eds. D. Fiorino, \& M. Pintus, Giannini ed.: Napoli, pp. 128-172, 2015.

[18] Gazzola, P., La difesa del rudere in Castellum no. 5, Istituto Nazionale dei Castelli: Roma, p. 9, 1967.

[19] Gizzi, S., La condizione del rudere in Sardegna. Santa Maria di Curos in territorio di Monteleone. Studi e restauri di un edificio allo stato di rudere, ed. G. Frulio, Soprintendenza per i beni architettonici il paesaggio e il patrimonio storico artistico ed etnoantropologico per le province di Sassari e Nuoro ed., p. 3, 2006.

[20] Billeci, B., Brandi in Sardegna. Una postfazione agli atti tra alcune riflessioni. Cesare Brandi e la Sardegna. Archeologia e paesaggio, eds. B. Billeci \& S. Gizzi, Gangemi ed.: Roma, p. 183, 2010.

[21] Brandi, C., Teoria del restauro, Enaudi ed.: Torino, pp. 29-47, 1977.

[22] Panedda, D., Il Giudicato di Gallura. Curatorie e centri abitati, Libreria Dessì ed.: Sassari, 1978.

[23] Cadeddu, M.E. ed., Studi storici sulle istituzioni della Sardegna nel Medioevo, Ilisso: Nuoro, 2001.

[24] Castellaccio, A., Olbia nel medioevo. Aspetti politico-istituzionali. Da Olbìa ad Olbia, 2500 anni di storia di una città mediterranea, eds. G. Meloni \& P.F. Simbula (Proceedings of the International Conference, Olbia, 12-14 Maggio 1994), Vol. II, Chiarella: Sassari, pp. 33-70, 1996.

[25] Meloni, G., L'origine dei Giudicati. Storia della Sardegna, eds. M. Brigaglia, A. Mastino \& G.G. Ortu, Vol. 2, Laterza ed. Roma-Bari, pp. 1-32, 2002.

[26] Ortu, G.G., I giudicati: storia, governo e società. Storia della Sardegna, eds. M. Brigaglia, A. Mastino \& G.G. Ortu, Vol. 2, Roma-Bari: Laterza, pp. 33-64, 2002.

[27] Rassu, M., Rocche Turrite. Guida ai castelli medievali della Sardegna, Grafica del Parteolla: Dolianova, pp. 101-102, 2007.

[28] Floris G., Il castello medioevale della Fava (Posada), Acta historica et archaeologica mediaevalia, pp. 257-277, Gen. 2008. 